\title{
MANUAL EXPRESSION OF THE BLADDER FOLLOWING SPINAL INJURY
}

\author{
By P. H. Smith, M.B., F.R.C.S., J. B. Cook, M.D., F.R.C.P., \\ and J. R. RHIND, M.B., Ch.B. \\ Leeds Regional Spinal Injuries Unit, Pinderfields General Hospital, Wakefield \\ and St. Fames's Hospital, Leeds.
}

\section{INTRODUCTION}

VeLLACOTT (1919), observing that 47 to 65 per cent. of patients suffering spinal injury in World War I died within a few weeks 'practically all from urinary infection', discussed the advantages and disadvantages of non-interference, manual expression, suprapubic cystotomy and urethral catheterisation. He concluded that none of the methods was ideal and that the technique of manual expression 'can only be advocated in those cases in which it is easily accomplished and in which the urine is not infected'. In such patients, however, he considered 'that passive treatment, i.e. allowing distension and overflow to take place should be given a thorough trial' and that 'attempts at expression should be made from time to time'.

Despite the advances of the last 50 years, infection of the urinary tract is still a major problem in the paraplegic patient and it seemed to us that the management of the bladder in the early weeks after spinal injury deserved further study. The possibility that manual expression of the bladder would promote adequate urinary drainage and the hope that this would be followed by reflex micturition suggested that it might be possible to avoid catheterisation throughout the acute phase and subsequent rehabilitation. No thorough trial of such a technique seems to have been undertaken though Golding (1968) reported good results with manual expression in 25 patients with traumatic paraplegia observed over three years. He found that an automatic bladder developed in 7 to 30 days, that the residual urine volume slowly decreased and that all patients had a normal intravenous pyelogram (I.V.P.). We report our findings in six patients similarly treated for 2 to 8 weeks after spinal injury.

\section{METHOD}

Six patients admitted to the Leeds Regional Spinal Injuries Unit at Pinderfields General Hospital without prior catheterisation were treated by manual expression of the bladder at four-hourly intervals. A further group of six patients treated by intermittent or continuous catheterisation served as controls. A limited I.V.P. (with films at Io minutes and 20 minutes in most patients) was carried out and a mid-stream specimen of urine (M.S.U.) obtained within 24 hours of admission and thereafter at weekly intervals in each patient. Prophylactic antibiotics were not used.

\section{RESULTS}

The results in the non-catheterised patients are illustrated in Table I. In every patient the pyelogram taken on admission was normal and the urine was sterile but 
TABLE I

Results of Non-Catheterisation of Six Male Patients following Spinal Injury

\begin{tabular}{|c|c|c|c|c|c|c|c|c|c|c|c|c|c|c|c|}
\hline \multirow[b]{2}{*}{ No. } & \multirow[b]{2}{*}{ Name } & \multirow[b]{2}{*}{ Age } & \multirow[b]{2}{*}{ Lesion } & \multirow{2}{*}{$\begin{array}{l}\text { Investi- } \\
\text { gations }\end{array}$} & \multicolumn{9}{|c|}{ Weekly results } & \multirow{2}{*}{$\begin{array}{l}\text { Deep vein } \\
\text { thrombosis }\end{array}$} & \multirow{2}{*}{$\begin{array}{l}\text { Present } \\
\text { condition }\end{array}$} \\
\hline & & & & & 0 & I & 2 & 3 & 4 & 5 & 6 & 7 & 8 & & \\
\hline I. & B. F. & I8 & $\mathrm{C} 4 / 5$ & $\begin{array}{l}\text { I.V.P. } \\
\text { M.S.U. }\end{array}$ & $\begin{array}{l}\mathrm{N} \\
-\end{array}$ & $\begin{array}{l}\mathrm{E} \\
-\end{array}$ & $\begin{array}{l}M \\
--\end{array}$ & $\begin{array}{l}M \\
-\end{array}$ & $\begin{array}{l}M \\
-\end{array}$ & $\begin{array}{l}M \\
+\end{array}$ & $\begin{array}{l}M \\
+\end{array}$ & $\begin{array}{l}S \\
+\end{array}$ & $\begin{array}{l}S \\
+\end{array}$ & - & $\begin{array}{l}\text { Well. Indwelling } \\
\text { catheter }\end{array}$ \\
\hline 2. & R. H. & 22 & D7 & $\begin{array}{l}\text { I.V.P. } \\
\text { M.S.U. }\end{array}$ & $N$ & $\begin{array}{l}\mathrm{E} \\
-\end{array}$ & $\begin{array}{l}\mathrm{E} \\
-\end{array}$ & $\begin{array}{l}M \\
-\end{array}$ & $\begin{array}{l}M \\
-\end{array}$ & $\begin{array}{l}S \\
-\end{array}$ & $\overline{+}$ & $\begin{array}{l}M \\
+\end{array}$ & $\begin{array}{l}M \\
+\end{array}$ & - & $\begin{array}{l}\text { Bilateral } \\
\text { hydronephrosis and } \\
\text { hydroureter } \\
\text { Bilateral reflux } \\
\text { Indwelling catheter }\end{array}$ \\
\hline 3. & R. J. & I9 & $\mathrm{C}_{7}$ & $\begin{array}{l}\text { I.V.P. } \\
\text { M.S.U. }\end{array}$ & $\begin{array}{l}\mathrm{N} \\
-\end{array}$ & $\begin{array}{l}\mathrm{E} \\
-\end{array}$ & $\begin{array}{l}M \\
-\end{array}$ & $\begin{array}{l}M \\
+\end{array}$ & $\begin{array}{l}S \\
+\end{array}$ & $\begin{array}{l}S^{\star} \\
+\end{array}$ & $\begin{array}{l}M \\
+\end{array}$ & $\begin{array}{l}M \\
+\end{array}$ & $\begin{array}{l}\mathrm{E} \\
+\end{array}$ & - & Well. Condom urinal \\
\hline 4. & A. B. & I5 & $\mathrm{C} 4 / 5$ & $\begin{array}{l}\text { I.V.P. } \\
\text { M.S.U. }\end{array}$ & $\begin{array}{l}\mathrm{N} \\
-\end{array}$ & $\begin{array}{l}\mathrm{E} \\
-\end{array}$ & $\begin{array}{l}M^{\star} \\
+\end{array}$ & $\begin{array}{l}\mathrm{N} \\
+\end{array}$ & $\begin{array}{l}\mathrm{N} \\
+\end{array}$ & $\begin{array}{l}\mathrm{N} \\
+\end{array}$ & + & + & - & + & $\begin{array}{l}\text { Well. Indwelling } \\
\text { catheter }\end{array}$ \\
\hline 5 & R. S. & $2 \mathrm{I}$ & DI2 & $\begin{array}{l}\text { I.V.P. } \\
\text { M.S.U. }\end{array}$ & $\begin{array}{l}\mathrm{N} \\
-\end{array}$ & $\begin{array}{l}\mathrm{E} \\
-\end{array}$ & $\begin{array}{l}M \\
-\end{array}$ & $\begin{array}{l}M^{\star} \\
-\end{array}$ & & & & & & + & $\begin{array}{l}\text { Well. Indwelling } \\
\text { catheter }\end{array}$ \\
\hline 6. & G. P. & I9 & $\mathrm{C} 4 / 5$ & $\begin{array}{l}\text { I.V.P. } \\
\text { M.S.U. }\end{array}$ & $\begin{array}{l}\mathrm{N} \\
-\end{array}$ & $\begin{array}{l}\mathrm{E} \\
-\end{array}$ & $\begin{array}{l}M \\
-\end{array}$ & $\begin{array}{r}\text { Die } \\
\text { er }\end{array}$ & $\begin{array}{l}\text { of } \\
\text { nbol }\end{array}$ & $\begin{array}{l}\text { pulm } \\
\text { us on }\end{array}$ & onar & y day & & + & \\
\hline
\end{tabular}

I.V.P. N, Normal, E, Early, M, Moderate, S, Severe, dilatation of upper renal tracts.

M.S.U. -, Sterile; +, Infected.

* Catheterised. (Patients I, 2, 6, were not catheterised during the period of this study.) 
all subsequent films showed evidence of dilatation of one or both upper renal tracts. Bacteriological evidence of urinary infection developed in all patients in whom manual expression was continued. Clinical evidence of deep vein thrombosis occurred in three patients one of whom died of pulmonary embolism. Eventually

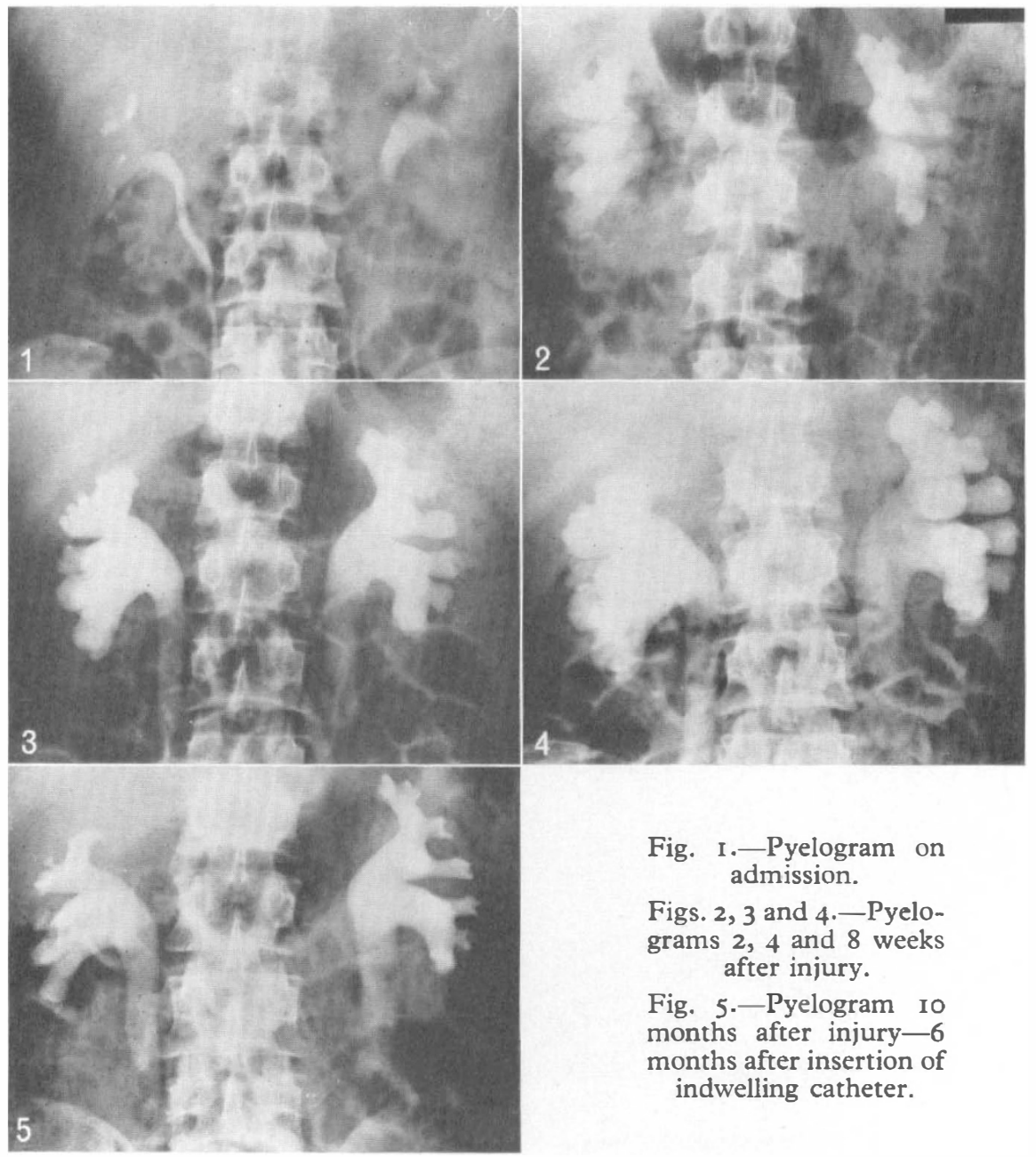

Figs. I-5

To show the pyelographic changes following manual expression of bladder after spinal injury.

it became necessary to catheterise every patient, this being followed by improvement in the changes in the upper tracts (figs. I-5). All the surviving patients are now well.

Table II shows the results in the catheterised patients and it will be seen that the I.V.P. remained normal in these patients throughout the period of study (figs. 6-9) whilst the occurrence of urinary infection was similar to that in the 
TABLE II

Results of Catheterisation of Six Male Patients following Spinal Injury

\begin{tabular}{|c|c|c|c|c|c|c|c|c|c|c|c|c|c|c|c|}
\hline \multirow[b]{2}{*}{ No. } & \multirow[b]{2}{*}{ Name } & \multirow[b]{2}{*}{ Age } & \multirow[b]{2}{*}{ Lesion } & \multirow{2}{*}{$\begin{array}{l}\text { Investi- } \\
\text { gations }\end{array}$} & \multicolumn{9}{|c|}{ Weekly results } & \multirow{2}{*}{$\begin{array}{l}\text { Deep vein } \\
\text { thrombosis }\end{array}$} & \multirow{2}{*}{$\begin{array}{l}\text { Present } \\
\text { condition }\end{array}$} \\
\hline & & & & & 0 & I & 2 & 3 & 4 & 5 & 6 & 7 & 8 & & \\
\hline I. & L. C. & 39 & $\mathrm{C}_{5} / 6$ & $\begin{array}{l}\text { I.V.P. } \\
\text { M.S.U. }\end{array}$ & $\underline{N}$ & $\begin{array}{l}\mathrm{N} \\
-\end{array}$ & $\begin{array}{l}N \\
-\end{array}$ & N & $\begin{array}{l}\mathrm{N} \\
-\end{array}$ & $\begin{array}{l}\mathrm{N} \\
-\end{array}$ & $\begin{array}{l}\mathrm{N} \\
+\end{array}$ & $\begin{array}{l}\mathrm{N} \\
+\end{array}$ & $\begin{array}{l}\mathrm{N} \\
+\end{array}$ & - & $\begin{array}{l}\text { Well. Intermittent } \\
\text { catheterisation }\end{array}$ \\
\hline 2. & A. H. & 20 & $\mathrm{C}_{4} / 5$ & $\begin{array}{l}\text { I.V.P. } \\
\text { M.S.U. }\end{array}$ & $\begin{array}{l}\mathrm{N} \\
-\end{array}$ & $\begin{array}{l}N \\
-\end{array}$ & $\begin{array}{l}\mathrm{N} \\
-\end{array}$ & $\begin{array}{l}\mathrm{N} \\
+\end{array}$ & $\begin{array}{l}N \\
+\end{array}$ & $\begin{array}{l}\mathrm{N} \\
+\end{array}$ & $\begin{array}{l}\mathrm{N} \\
+\end{array}$ & $\begin{array}{l}\mathrm{N} \\
+\end{array}$ & $\begin{array}{l}\mathrm{N} \\
+\end{array}$ & - & $\begin{array}{l}\text { Well. Indwelling } \\
\text { catheter }\end{array}$ \\
\hline 3. & S. J. & 60 & C6/7 & $\begin{array}{l}\text { I.V.P. } \\
\text { M.S.U. }\end{array}$ & - & - & $\begin{array}{l}M \\
-\end{array}$ & $\begin{array}{l}\mathrm{N} \\
+\end{array}$ & $\begin{array}{l}\mathrm{N} \\
+\end{array}$ & $\begin{array}{l}N \\
+\end{array}$ & $\begin{array}{l}\mathrm{N} \\
+\end{array}$ & $\begin{array}{l}\mathrm{N} \\
-\end{array}$ & $\begin{array}{l}N \\
-\end{array}$ & - & $\begin{array}{l}\text { Well. Normal } \\
\text { Bladder }\end{array}$ \\
\hline 4. & G. S. & 40 & $\mathrm{D}_{\mathrm{II} / \mathrm{I} 2}$ & $\begin{array}{l}\text { I.V.P. } \\
\text { M.S.U. }\end{array}$ & - & $\begin{array}{l}\mathrm{N} \\
-\end{array}$ & $\begin{array}{l}\mathrm{N} \\
+\end{array}$ & $\begin{array}{l}\mathrm{N} \\
+\end{array}$ & $\begin{array}{l}\mathrm{N} \\
+\end{array}$ & $\begin{array}{l}N \\
-\end{array}$ & $\begin{array}{l}\mathrm{N} \\
+\end{array}$ & $\begin{array}{l}\mathrm{N} \\
+\end{array}$ & $\begin{array}{l}N \\
+\end{array}$ & - & $\begin{array}{l}\text { Well. Indwelling } \\
\text { catheter }\end{array}$ \\
\hline 5. & J. W. & 23 & $\mathrm{C}_{4} / 5$ & $\begin{array}{l}\text { I.V.P. } \\
\text { M.S.U. }\end{array}$ & - & $\begin{array}{l}\mathrm{N} \\
-\end{array}$ & $\begin{array}{l}\mathrm{N} \\
-\end{array}$ & $\begin{array}{l}\mathrm{N} \\
-\end{array}$ & $\begin{array}{l}\mathrm{N} \\
+\end{array}$ & $\begin{array}{l}\mathrm{N} \\
+\end{array}$ & $\begin{array}{l}\mathrm{N} \\
+\end{array}$ & $\overline{+}$ & $\overline{-}$ & + & $\begin{array}{l}\text { Well. Indwelling } \\
\text { catheter }\end{array}$ \\
\hline 6. & L. G. & 58 & $C_{5} / 6$ & $\begin{array}{l}\text { I.V.P. } \\
\text { M.S.U. }\end{array}$ & - & - & $\begin{array}{l}\mathrm{N} \\
+\end{array}$ & $\begin{array}{l}\mathrm{N} \\
+\end{array}$ & $\begin{array}{l}\mathrm{N} \\
+\end{array}$ & $\begin{array}{l}\mathrm{N} \\
+\end{array}$ & - & 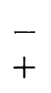 & $\begin{array}{l}\mathrm{N} \\
+\end{array}$ & - & $\begin{array}{l}\text { Well. Indwelling } \\
\text { catheter }\end{array}$ \\
\hline
\end{tabular}


catheterised group. These patients are also well. Deep vein thrombosis was detected in only one of the catheterised patients.

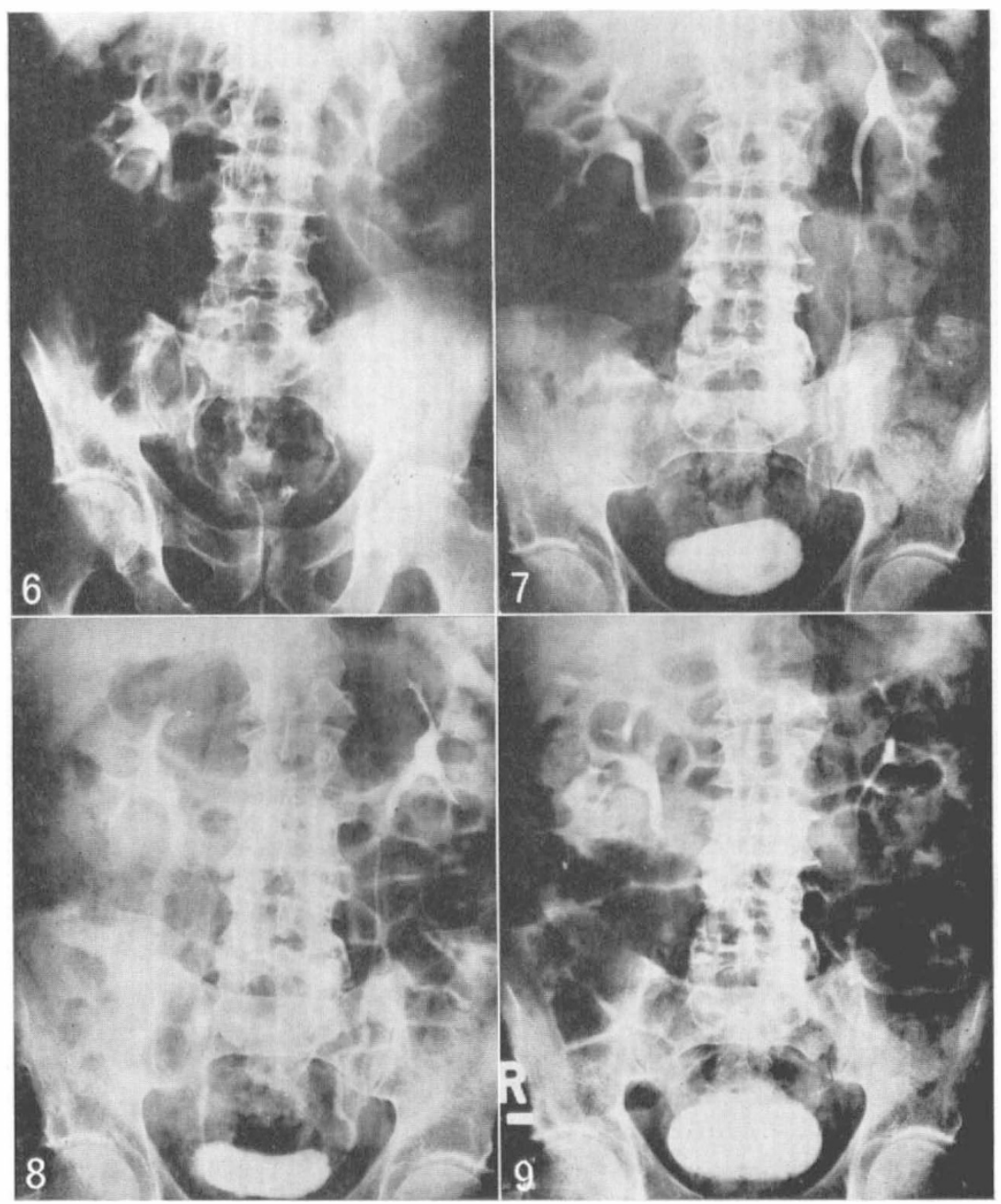

Figs. 6-9

To show the pyelographic changes following catheterisation of the bladder after spinal injury.

Fig. 6.-Pyelogram on admission.

Figs. 7, 8 and 9.-Pyelogram 2, 3 and 8 weeks after injury.

\section{DISCUSSION}

Recurrent or persistent infection of the urinary tract is still far too common in the paraplegic and the late results of such infections and of obstruction are even now responsible for 60-70 per cent. of the deaths in these patients. This study was carried out in the hope that the technique of non-catheterisation in those with a 
sterile urine and in whom manual expression could be carried out with ease, would prevent the initial infection and so improve the long-term outlook, since in our hands at least, prolonged urethral catheterisation, whether continuous or intermittent, is nearly always followed by a urinary infection.

Though bladder function returned in several patients within eight weeks we believe that manual expression is unsatisfactory because of pyelographic evidence of increasing obstruction in the urinary tract, the development of spontaneous urinary infection (previously noted by Vellacott, 1919) and the apparent high incidence of deep vein thrombosis in those patients who were not catheterised. Though the figures for deep vein thrombosis are by no means statistically significant it is of interest to note that Young and Mitchell (I968) have previously observed obstruction of the iliac veins in association with massive bladder distension. We feel that this technique is not suitable for general use.

\section{SUMMARY}

Manual expression of the bladder following spinal injury is unsatisfactory since it is followed by dilatation of the upper urinary tracts, the spontaneous development of cystitis and an apparently increased incidence of deep vein thrombosis. Our results differ from those of Golding (1968) and we feel that this technique should be discarded.

\section{ACKNOWLEDGMENTS}

We should like to acknowledge our debt to the Nursing Staff of the Spinal Injuries Unit for their ever helpful attitude and to the Department of Medical Photography of St. James's Hospital for the illustrations.

\section{REFERENCES}

Golding, J. S. R. (1968). Rehabilitation. No. 66. 49-53.

VELLACOTT, P. N. (I919). Lancet, I, 733-737.

Young, T. W. \& Mitchell, J. P. (I968). Brit. F. Urol. 40, 248-250. 